Hydrol. Earth Syst. Sci. Discuss., https://doi.org/10.5194/hess-2018-184

Manuscript under review for journal Hydrol. Earth Syst. Sci.

Discussion started: 2 May 2018

\title{
Explorative Analysis of Long Time Series of Very High Resolution Spatial Rainfall
}

Emma Dybro Thomassen ${ }^{1}$, Hjalte Jomo Danielsen Sørup ${ }^{1}$, Marc Scheibel ${ }^{2}$, Thomas Einfalt ${ }^{3}$, Karsten Arnbjerg-Nielsen ${ }^{1}$

$5 \quad{ }^{1}$ Department of Environmental Engineering, Technical University of Denmark, Lyngby, 2800, Denmark

${ }^{2}$ Wupperverband, Wuppertal, 42289, Germany

${ }^{3}$ hydro \& meteo GmbH\&Co.KG, Lübeck, 23552, Germany

Correspondence to: Emma Dybro Thomassen (edth@env.dtu.dk)

Abstract. Rainfall is often represented by a design storm with uniform intensity in urban hydrological models even though

10 rainfall is a highly dynamic process across very small temporal and spatial scales. This study examines characteristics of highresolution radar data (5-minute temporal resolution, $1 \times 1 \mathrm{~km}$ spatial resolution) over an area of $1824 \mathrm{~km}^{2}$ covering the catchment of the river Wupper, North Rhine-Westphalia, Germany. Extreme events were sampled by a Peak Over Threshold method using several sampling strategies, all based on selecting an average of three events per year. A simple identificationand tracking algorithm for rain cells based on intensity threshold and fitting of ellipsoids, is developed for the study. Both

15 hourly and daily extremes were analysed with respect to a set of 16 descriptive variables. The spatio-temporal properties of the extreme events are explored by means of principal component analysis, cluster analysis, and linear models for these 16 variables. The PCA indicated between 5 and 9 dimensions in the extreme event characteristic data. The cluster analyses identified four rainfall types: extreme convective, convective, convective events in front systems and front system events. The stepwise regression for each variable identified independent variables that correspond well with the correlation structure identified in the clusters. This indicates that the correlation structure may prove useful in setting up a weather generator.

\section{Introduction}

Urban hydrological models of high quality are a required tool to make cities more resilient to pluvial flooding and pollution management. A key input parameter when modelling urban drainage systems is rainfall (Berndtsson and Niemczynowicz, 1988; Schilling, 1991; Thorndahl et al., 2008; Vaes et al., 2001). A common way is to use a model including a rainfall-runoff component that uses rainfall input as either a long-term rainfall series or a design storm (Butler and Davies, 2011; Willems et al., 2012). For some applications rainfall data must be of high spatial and temporal resolution (Berndtsson and Niemczynowicz, 1988; Einfalt et al., 2004; Ochoa-Rodriguez et al., 2015; Schilling, 1991). Schilling (1991) and Einfalt et al. (2004) have proposed resolution requirements of 1-5 minute temporal resolution and $1 \mathrm{x} 1$ kilometre spatial resolution. 
Hydrol. Earth Syst. Sci. Discuss., https://doi.org/10.5194/hess-2018-184

Manuscript under review for journal Hydrol. Earth Syst. Sci.

Discussion started: 2 May 2018

(c) Author(s) 2018. CC BY 4.0 License.

Inference on properties of rainfall can be based upon two types of data: rain gauge and radar data. Both types of data have significant strengths and weaknesses. Rain gauge data require less data treatment compared to radar data, and measurements are often available for longer time periods. Rain gauges measure rainfall at ground level, which is the rainfall of interest in hydrological modelling (Thorndahl et al., 2016), and often have a temporal resolution of around 1 minute (Einfalt et al., 2004).

5 A major weakness about rain gauge data is the lack of information on rainfall movement (mainly for convective events), spatial variation and coverage. Radar data, on the other hand, gives information about rainfall movement and spatial coverage (Thorndahl et al., 2016), and have significantly improved our understanding of how precipitation is formed (Collier, 1989). Weaknesses of radar data is that rainfall intensities are inferred based on reflectivity with often very high uncertainties for high rainfall intensities. Furthermore, radar data is based on an instantaneous scan of volume high above ground that is then used

10 to represent the average rainfall intensity during the entire sampling time. This can lead to aggregation errors and might not reflect the rainfall at ground level (Einfalt et al., 2004).

Weather Generators (WG) to simulate rainfall are numerous and diverse in kind, input data, spatial and temporal scale (Arnbjerg-Nielsen et al., 2013; Wilks and Wilby, 1999). In the field of rainfall simulation, focus has until now been on models

15 based on rain gauge data and hence several WGs model precipitation as a stochastic point process (Burton et al., 2008; Cowpertwait and O'Connell, 1997; Onof and Arnbjerg-Nielsen, 2009). Weather generators can be based upon a dense network of rain gauges in order to include some spatial variation in the model (e.g. Jinno et al. (1993); Willems (2012); Sørup et al. (2016)) but none of these WGs describe the spatial dynamics of rainfall at a resolution suitable for urban hydrology.

20 Radar data has been suggested as potential rainfall input in urban hydrology since the mid 80's (Einfalt et al., 2004). Radar products have more recently become available in spatial and temporal resolution fulfilling the resolution requirement in urban hydrology, and has within the last 1-2 decades become more frequently used in urban hydrology along with increasing length of recording period (Thorndahl et al., 2016). Weather generators based on high resolution radar data are very limited, and often rely heavily on statistically based variables (e.g. Peleg and Morin, (2012)). The downside of this is the absence of physically

25 based variables to represent the spatio-temporal variation in rainfall and thereby enabling linking WGs to e.g. climate change models.

This study aims to quantify and describe spatial rainfall as a function of temporal and spatial dynamics, rainfall types and seasonal variation. Descriptive statistical methods are applied to analyse selected physically based variables and their internal 30 correlation. The study aims to statistically describe spatio-temporal varying rainfall using physically based variables, in order to assess the possibility of creating artificial spatio-temporal rainfall series, of high resolution scales useful for urban hydrology. 
Hydrol. Earth Syst. Sci. Discuss., https://doi.org/10.5194/hess-2018-184

Manuscript under review for journal Hydrol. Earth Syst. Sci.

Discussion started: 2 May 2018

(c) Author(s) 2018. CC BY 4.0 License.

\section{Data and case area}

\subsection{Case area}

The case area is a $38 \mathrm{x} 48 \mathrm{~km}$ rectangle $\left(1824 \mathrm{~km}^{2}\right)$ surrounding the catchment of the river Wupper in North Rhine-Westphalia, Germany. It stretches from the Rhine lowland in southwest to the more hilly area in east, with steep valleys around the river

5 Wupper. The elevation varies from 31 meters to 483 meters above sea level (see Figure 1). The mean annual precipitation in the area ranges from $770 \mathrm{~mm}$ to $1352 \mathrm{~mm}$, due to strong orographic effects, with lowest precipitation in low lying areas and most precipitation in the highest elevated areas (orographic rainfall). Due to partly high urbanisation, small-scale but highly intense convective rainfall causes flash floods with a huge damage potential, Therefore, a good knowledge about the structures and impacts of different storm types on a high resolution is essential for planning and forecasting matters.

\section{$10 \quad 2.2$ Data}

Radar data from the Deutsche Wetterdienst (DWD) Doppler C-band radar network was used in this study (5-minute temporal resolution, $1 \mathrm{x} 1 \mathrm{~km}$ spatial resolution). The data comes from the Wupper Association and spans 13 years, from the $1^{\text {st }}$ of November 2000 to the $1^{\text {st }}$ of November 2013. The case area is within the range of the Essen radar and partly within the range of the Flechtdorf and Neuheilenbach radars. The data is a weighted composition of the three radars (Einfalt and Lobbrecht, 15 2011).

The data is post processed by hydro \& meteo GmbH \& Co. KG on behalf of the Wupper Association. Data is corrected in regards of blockage, clutter and attenuation. The reflectivity $(\mathrm{Z})$ rainfall intensity $(\mathrm{R})$ relationship is fixed as $Z=256 \cdot R^{1.42}$. In the Wupper Association district the radar data is adjusted to rain gauge data on a daily basis, with a correction factor per

20 gauge in a $1 \mathrm{~km}$ correction grid using inverse distance weighting. Rain gauge data is beforehand visually inspected and compared to nearby gauges in order to secure the quality. There are 60 rain gauges within the area of the Wupper Association. The post processed data have less than $5 \%$ difference from annual ground truth (Frerk et al., 2012)

\section{Methodology}

\subsection{Extreme events}

25 Extreme events are identified based on time series data and defined based on a Peak Over Threshold method (Coles, 2001). A Type II censoring is applied with a prefixed number of 39 extreme events, equal to an average of 3 events per year (Mikkelsen et al., 1995). Two types of extreme events are considered, 1-hour and 24-hour extreme events, based on the maximum average intensity for either 1 hour or 24 hours. 
Hydrol. Earth Syst. Sci. Discuss., https://doi.org/10.5194/hess-2018-184

Manuscript under review for journal Hydrol. Earth Syst. Sci.

Discussion started: 2 May 2018

(c) Author(s) 2018. CC BY 4.0 License.

\subsection{Spatial selection of extreme events}

The extreme event definition is based on time series of point data. To our knowledge there is no generally applied procedure to sample extreme events from multisite or areal measurements such as radar data. Based on time series data we examine four methods to identify rain events in order to determine the number of grid cells which should be considered when selected extreme events for further analyses. All methods identify the number of rain events in the data period, average length of rain events, average maximum number of grid cells registering each event, and seasonal distribution of rain events. The sampling strategies (SS) are listed below in order of increasing number of grid cells:

SS1. $\quad$ Sampling from 1 grid cell

SS2. $\quad$ Sampling from 5 grid cells

10 SS3. Sampling from one side of the mountains (every ninth grid cell)

SS4. Sampling from the entire catchment (every ninth cell)

\section{SS1, Sampling from 1 grid cell}

The simplest sampling strategy is choosing one grid cell from which rain events are identified. Rain events separated by dry

15 periods less than 24 hours apart are aggregated to one event in accordance with (Madsen et al., 2002, 2009). The single grid cell considered is shown in Figure 2.

\section{SS2, Sampling from 5 grid cells}

The second sampling strategy considers 5 grid cells in a spatially small area on the same side on the mountain as the

20 predominant wind direction (west wind, see Figure 2). Precipitation occurs when at least one of the locations measures rainfall and events are aggregated using the same approach as when sampling from one grid cell.

\section{SS3, Sampling from one side of the mountain (every ninth grid cell)}

The third sampling strategy for rain events considers a larger part of the catchment. Due to the strong orographic effect, the

25 part of the catchment which is on the same side of the mountains and therefore located on the same side where the main part of the weather arrives from is considered. Every ninth grid cell in this area is selected with a total of 104 grid cells (see Figure 2). Precipitation events are defined using the same approach as when sampling from 5 grid cells.

SS4, Sampling from the entire catchment (every ninth grid cell)

30 The fourth sampling strategy concerns the entire catchment. Every ninth grid cell is selected, and precipitation time series are merged with a 24-hour dry period between independent events. A total of 187 grid cells are considered. 
Hydrol. Earth Syst. Sci. Discuss., https://doi.org/10.5194/hess-2018-184

Manuscript under review for journal Hydrol. Earth Syst. Sci.

Discussion started: 2 May 2018

(c) Author(s) 2018. CC BY 4.0 License.

\subsection{Data analysis}

\subsubsection{Seasonal variation}

The seasonal variation of occurrence of extreme events from the five grid cells filled in Figure 2 is analysed for 1-hour and 24-hour extreme events. The analysis is based on four seasons: winter (December-February), spring (March-May), summer

(June-August) and fall (September-November).

\subsubsection{Spatial correlation}

The spatial correlation between 4950 pairs of grid cells (100 randomly selected grid cells) is calculated, applying the framework of spatial correlating structures by Mikkelsen et al. (1996). The method calculates the spatial correlation by estimating the correlation of extreme events that are meteorologically dependent. The unconditional correlation coefficient $\rho$ between a pair

10 of grid cells $(A$ and $B)$ is calculated by identifying concurrent events. If it is assumed that the start $(t \mathrm{~s})$ and end ( $t$ e) times of all events are known, concurrence between the $i$ th event at grid cell $\mathrm{A}, Z \mathrm{~A} i$ and the $j^{\prime}$ th event at grid cell $\mathrm{B}, Z \mathrm{~B} j$ is defined as:

$\left\{Z_{A i}, Z_{B i}\right\}:\left[t_{s i}-\frac{1}{2} \Delta t, t_{e i}+\frac{1}{2} \Delta t\right]_{A} \cap\left[t_{s i}-\frac{1}{2} \Delta t, t_{e i}+\frac{1}{2} \Delta t\right]_{B} \neq \emptyset$

where $\Delta t$ is a lag time introduced to ensure that events can be concurrent events though travelling time means that these events do not overlap in time. $\Delta t$ was in this study set to 11 hours equal to the $\Delta t$ used in Gregersen et al. (2013). Based on the sample

15 of concurrent events and the sample of not concurrent events in a pair of grid cells, the unconditional covariance is estimated as:

$\operatorname{Cov}\left\{Z_{A}, Z_{B}\right\}=\operatorname{Cov}\left\{E\left\{Z_{A} \mid U\right\}, E\left\{Z_{B} \mid U\right\}\right\}+E\left\{\operatorname{Cov}\left\{Z_{A}, Z_{B} \mid U\right\}\right\}$

Given by the definition in Mikkelsen et al. (1996), the unconditional correlation coefficient $\rho$ can now be estimated by dividing the unconditional covariance with the standard deviation for the two stations. Following the procedure proposed by Gregersen

20 et al. (2013) the data is hereafter divided into bins based on distance between stations and the average $\rho$ for each bin is calculated in order to minimise noise in the data set. An exponential function is fitted to data, relating the distance between a pair of stations with the unconditional correlation coefficient $\rho$. The e-folding distance is then found as the distance where the unconditional correlation have decreased to 1/e, based on the fitted exponential function (Gregersen et al., 2013).

\subsubsection{Spatial variation}

25 The spatial variation in extreme events is analysed for the five grid cells filled in Figure 2. The extreme events sampled from each of the five grid cells, are compared to identify the small-scale variability in sampled extreme events. The black filled grid cell is used as reference and compared to the four grey filled grid cells. The number of concurrent events and the distance between the grid cells are calculated. 
Hydrol. Earth Syst. Sci. Discuss., https://doi.org/10.5194/hess-2018-184

Manuscript under review for journal Hydrol. Earth Syst. Sci.

Discussion started: 2 May 2018

(c) Author(s) 2018. CC BY 4.0 License.

\subsection{Characterisation of events}

The two sets of 39 extreme events are characterised by 16 variables chosen to describe a variety of event properties (see Table 1); these can be further aggregated into six categories: Duration, intensity, wet area coverage, depth, rain cell properties and movement. Rain cell properties and movement are described with a simple rain cell identification and tracking algorithm as described below.

\subsubsection{Rain cell identification}

Rain cells are identified in each time step by assigning an intensity threshold and an areal threshold. The intensity threshold is set to $25 \%$ of the maximum 5-minute intensity for the given event with a minimum threshold of $7 \mathrm{~mm} \mathrm{~h}^{-1}$. The areal threshold is set to a minimum coverage of $10 \mathrm{~km}^{2}$. An event specific threshold is chosen to distinguish between different rain cell types

10 (e.g. convective and front cells) and secure a high threshold for all events which result in a more stable tracking of a clear cell centre (Dixon and Wiener, 1993). Rain cells with an area below the areal threshold are disregarded to avoid noise in the overall tracking from multiple small cells (Dixon and Wiener, 1993). An ellipse is fitted to each of the identified rain cells, with the coordinates for the centroid, length of the axis and orientation in degrees between major axis and east-axis (Belachsen et al., 2017; Peleg and Morin, 2012).

\section{$15 \quad 3.4 .2$ Rain cell tracking}

Various complex rain cell tracking algorithms can be found in literature (e.g. Dixon and Wiener, 1993; Handwerker, 2002; Kyznarová and Novák, 2009). For describing the overall moving direction and velocity of each rain event this study has developed a simple tracking algorithm. Rain cell movement is recorded by linking the identified rain cells in each time step together in a simple tracking algorithm based on the position of the centroid. Tracking is based on the moving direction and

20 velocity from last time step which is used to predict the approximate position of the rain cell in the next time step. The rain cell with the centroid closest to the predicted position of the rain cells centroid is linked to the rain cell in the previous time step with no further evaluation of the fit. A maximum distance of $7.5 \mathrm{~km}$, corresponding to a moving velocity of $25 \mathrm{~m} \mathrm{~s}^{-1}$, from the predicted position of the rain cell to the linked rain cell is applied. For new rain cells, the position of the rain cell in time step one is the predicted position of the rain cell in next time step. The tracking algorithm manages birth, tracking and death of rain cells. If splitting of a rain cell occurs, the algorithm will treat it as continuous tracking of the rain cell and a birth of a new rain cell. In case of merging of two rain cells, the algorithm will classify it a death of one rain cell and continue tracking of the other rain cell.

\subsection{Statistical analyses}

All statistical analyses are performed using normalised data, i.e. mean zero and variance one. All analyses are carried out in R 30 using the build-in R Stats Package version 3.4.1. 
Hydrol. Earth Syst. Sci. Discuss., https://doi.org/10.5194/hess-2018-184

Manuscript under review for journal Hydrol. Earth Syst. Sci.

Discussion started: 2 May 2018

(c) Author(s) 2018. CC BY 4.0 License.

\subsubsection{Principal component analysis}

Principal Component Analysis (PCA) is used to estimate the correlation structures in data and determine the number of dimensions necessary to describe it. PCA is a linear orthogonal transformation method to describe the variance of data using linear combinations, called Principal Components (PC).

Eigenvalues and corresponding vectors are calculated based on the correlation matrix of the normalised data. The eigenvector with the $i^{\text {th }}$ largest eigenvalue $\left(\lambda_{i}\right)$ is noted the $i^{\text {th }}$ principal axis, where $P C_{i}$ represent the projection of data on the $i^{\text {th }}$ principal axis (Morrison, 1967). The percentage of the variance, which $P C_{i}$ describes, is calculated as the percentage of the sum of the eigenvalues based on the $i^{\text {th }}$ eigenvalue (Morrison, 1967).

10

Two tests are applied to determine the number of dimensions necessary to describe data. The first test is an approximate test to estimate the number of significant PC's based on the magnitude of the eigenvalues. The hypothesis tested is that the last $k+1$ to $m$ eigenvalues are similar and therefore non-significant, where $m$ is the total number of eigenvalues. The test is described in Lawley and Maxwell (1963) and Anderson (1984) as:

$15 H_{0}: \lambda_{1} \geq \cdots \geq \lambda_{k} \geq \lambda_{k+1}=\cdots=\lambda_{m}$

The test statistic is defined as:

$z_{2}=-n * \ln \left(\frac{\prod_{i=k+1}^{m} \lambda_{i}}{\bar{\lambda}^{m-k}}\right)$

where $\hat{\lambda}$ is defined as:

$\hat{\lambda}=\sum_{i=k+1}^{m} \lambda /(m-k)$

20 The second test estimates the number of effective spatial degrees of freedom based on the eigenvalues and was proposed by Bretherton et al., (1999) as:

$N_{e f f}=\frac{\left(\sum_{i=1}^{m} \lambda_{i}\right)^{2}}{\sum_{i=1}^{m} \lambda_{i}^{2}}$

\subsubsection{Cluster analysis}

Partitioning and hierarchical clustering is performed on the dataset to identify similarities between the events based on all variables. Both clustering methods are based on the normalised data, i.e. the same dataset used for the PCA.

The K-means clustering algorithm presented by Hartigan (1975) and Hartigan and Wong (1979) is selected as partitioning clustering method. The method divides the dataset into a predefined number of clusters by minimising the sum of squared distances (Hartigan, 1975). Initially all events are assigned a cluster and it is afterwards for each event tested if the Euclidean

30 distance to the centre of the cluster will be reduced if the event is moved to another cluster. The centre of the cluster is defined as the mean of each of the PCs that the events in the cluster are projected onto and updated every time a cluster is moved from 
Hydrol. Earth Syst. Sci. Discuss., https://doi.org/10.5194/hess-2018-184

Manuscript under review for journal Hydrol. Earth Syst. Sci.

Discussion started: 2 May 2018

(c) Author(s) 2018. CC BY 4.0 License.

or added to the cluster. If $l(i)$ describes the cluster where the event $i$ is contained and $l$ represents any cluster then $D[i, l(i)]$ denotes the Euclidean distance between event $i$ and cluster centre $l(i)$ and similarly $D[i, l]$ denotes the Euclidean distance between event $i$ and the centre of any other cluster. Reallocation of events to another cluster is done if it decreases the error as:

$5 \quad \frac{\left.N_{l} D[i, l]\right]^{2}}{N_{l}+1}-\frac{N_{l} D[i, l(i)]^{2}}{N_{l(i)}+1}<0$

The hierarchical clustering methods selected are the Ward method and the Average Linkage Method (Murtagh, 1983). The methods are agglomerative clustering methods where all events start in separate clusters, the two less dissimilar events are joined until all events are in one cluster (Cormack, 1971). The dissimilarities between events are calculated based on the LanceWilliams cluster update method (Lance and Williams, 1966). As an example, assume that the dataset is divided into three

10 clusters, $h, i$ and $j$ with $n_{h}, n_{i}$, and $n_{j}$ number of events in each of the clusters and the dissimilarities between the clusters are denoted $d_{h i}, d_{h j}$ and $d_{i j}$. The dissimilarities between two events are calculated as the Euclidean distance between the events when all events are in separate clusters. If the dissimilarity between the clusters $i$ and $j$ is smallest, the two clusters are joined to the new cluster $\mathrm{k}$, with $n_{k}=n_{i}+n_{j}$ events. The dissimilarity between cluster $\mathrm{k}$ and $\mathrm{h}$ is calculated as:

$d_{h k}=\alpha_{i} d_{h i}+\alpha_{j} d_{h j}+\beta d_{i j}+\gamma\left(d_{h i}+d_{h j}\right)$

15 Where $\alpha_{i}, \alpha_{j}, \beta$ and $\gamma$ are parameters determined by the clustering method (Cormack, 1971). For the Ward method $\alpha_{i}=\left(n_{i}+\right.$ $\left.n_{k}\right) /\left(n_{i}+n_{j}+n_{k}\right), \beta=-n_{k} /\left(n_{i}+n_{j}+n_{k}\right)$ and $\gamma=0$ while for the Average Linkage $\alpha_{i}=n_{i} /\left(n_{i}+n_{j}\right), \beta=0$ and $\gamma=$ 0 . The results are illustrated using dendrograms.

\subsubsection{Stepwise regression}

Stepwise regression is used to estimate the number of independent variables which are necessary to describe a dataset (Draper and Smith, 1998). The method fits a linear model which is as simple as possible and as complex as necessary to data. Stepwise regression is performed with a stepwise forward selection of variables to include in the model and an evaluation of all variables in the model to test if any of the included variables should be eliminated (Rawlings et al., 1998). The Akaike's Information Criterion (AIC) (Akaike, 1971) is used to determine the trade-off between simplicity and fit:

AIC $=-2 \cdot$ LogLikelihood $+2 p$

25 Where $p$ is the number of parameters in the model, as the lower AIC the better fit $\mathrm{p}$ therefore acts like a penalty when adding more parameters. An optimal linear model is fitted to each of the 16 variables from the event analysis independently with the remaining variables as descriptors using stepwise regression. 
Hydrol. Earth Syst. Sci. Discuss., https://doi.org/10.5194/hess-2018-184

Manuscript under review for journal Hydrol. Earth Syst. Sci.

Discussion started: 2 May 2018

(c) Author(s) 2018. CC BY 4.0 License.

\section{Results and discussion}

\subsection{Spatial selection of extreme events}

For the four sampling strategies, the number of rain events in the data period, average length of rain events, average maximum number of grid cells registering each event, and seasonal distribution of rain events are shown in Table 2. The total number of events within the data period decreases substantially, and the average length increases similarly, when the number of grid cells considered is increased. The seasonal proportion of the events indicates that especially summer events are joined when more grid cells are considered. The results from Table 2 indicate that meteorologically independent events are joined when grid cells in a large part of the catchment is considered. In order to sample events which are meteorologically independent and use the knowledge about extreme events from rain gauge data, sampling method one, only considering one grid cell when sampling extreme events, is selected.

\subsection{Data analysis}

\subsubsection{Seasonal variation}

The seasonal variation of occurrence of extreme events for each of the five grid cells filled in Figure 2, can be seen in Figure 3. There is very little variation between the five stations in seasonal variation in occurrence of extreme events. In contrast to

15 this, the difference between 1-hour and 24-hour extreme events is more pronounced, with 1-hour extreme events almost only occurring in the summer while 24-hour extreme events are more uniformly distributed over the year. This corresponds well with the seasonal difference in precipitation in the area (ExUS, 2010; Quirmbach et al., 2012) and the expectance of differences in seasonal variation between different event types, convective vs. front events, (Gregersen et al., 2013).

\subsubsection{Spatial correlation}

20 The spatial correlations calculated between 4590 pairs of grid cells for 1-hour and 24-hour extreme events are shown in Figure 4. The spatial correlation for 1-hour extreme events decreases faster with distance than for the 24-hour extreme events. This indicates that 1-hour extreme events are more localised small-structured events while the 24-hour extreme events are spatially larger events. From the fitted exponential functions, the e-folding distances are calculated to be $9.3 \mathrm{~km}$ and 21.3 for 1-hour and 24-hour extreme events respectively. Studies calculating e-folding distances on rain gauge data show similar orders of magnitude and differences between 1-hour and 24-hour extreme events (Gregersen et al., 2013).

\subsubsection{Spatial variation}

The spatial variation of extreme events is indicated by calculating the similarity of choice of events by grid cells close to the chosen grid cell, see Table 3. Only approximately $55 \%$ of the 1-hour extreme events are the same events for the four surrounding grid cells (grey filled, Figure 2), when comparing to the reference grid cell (black filled, Figure 2), while $80 \%$ of 
Hydrol. Earth Syst. Sci. Discuss., https://doi.org/10.5194/hess-2018-184

Manuscript under review for journal Hydrol. Earth Syst. Sci.

Discussion started: 2 May 2018

the 24-hour extreme events are the same. This again indicates that 1-hour extreme events are very localised events and state the importance of carefully selecting a sampling strategy for analysed extreme events.

\subsection{Event characterisation}

1-hour and 24-hour extreme events sampled using sampling method one and described by the chosen 16 variables in the event

5 analysis can be found in the supplementary material. The 39 sampled 1-hour extreme events consist of 27 summer events and 12 non-summer events while the 39 24-hour extreme events consist of 9 summer events and 30 non-summer events. Differences between variables describing 1-hour and 24-hour extreme events are in particular pronounced for the variables Duration, Maximum 10 minute intensity and Maximum depth, which can be related to the differences between convective events and events within front systems. The results from the event characterisation, in relation with the results from the seasonal

10 variation and spatial correlation indicate that the events sampled are representative for extreme events over the year in the area. Twelve events occur in both 1-hour and 24-hour extreme events; these are listed in Table 4.

\subsection{Statistical analyses}

\subsubsection{Principal component analysis}

The PCA is performed on both the 1-hour and 24-hour extreme event dataset separately and as one dataset. The shown results

15 focus on the 1-hour and 24-hour extreme events treated as one dataset. In Table 5 the weighted composition of variables in each of the first nine PCs can be seen. $\mathrm{PC}_{1}$ and $\mathrm{PC}_{2}$ are influenced by most of the variables describing the means of the events. $\mathrm{PC}_{3}$ describe the movement of the rain cells in the events and is mostly influenced by Standard deviation of direction and Mean direction, which is not contributing much in $\mathrm{PC}_{1}$ and $\mathrm{PC}_{2}$, and Standard deviation of velocity. $\mathrm{PC}_{4}$ can be summarised to describe the extremity of the events, mostly influenced by Duration, Ratio 10min, Maximum 24hr intensity, Mean wet area

20 and Rain cell life time. The two first PCs explain $57.58 \%$ of the total variance and the first nine PCs should be considered if $95 \%$ of the variance must be explained. Based on the eigenvalues 14 PCs are significant when using the approximate test in Eq. (3-5). The alternative test suggests that there are 5.1 effective PCs. As such, five to nine dimensions should be, and up to 14 dimensions could be, considered in order to describe the variability of the events when considering both 1-hour and 24hour extreme events.

25

In Figure 5 the dataset is projected into the first two PCs. In the left figure the PCA is performed on the 24-hour dataset alone and the 1-hour extreme events are projected on to the two first PCs for the 24-hour extreme events, i.e. the 1-hour and 24-hour dataset are normalised separately. On the right the PCA is performed on the combined dataset, i.e. the 1-hour and 24-hour dataset are normalised together. While no distinct difference between 1-hour and 24-hour extreme events can be seen when

30 data is normalised separately (Figure 5, left), a clear clustering between 1-hour and 24-hour extreme events can be seen when data is normalised as one dataset and a combined PCA is performed (Figure 5, right). This indicates that the observed 
Hydrol. Earth Syst. Sci. Discuss., https://doi.org/10.5194/hess-2018-184

Manuscript under review for journal Hydrol. Earth Syst. Sci.

Discussion started: 2 May 2018

(c) Author(s) 2018. CC BY 4.0 License.

differences between 1-hour and 24-hour extreme events can be described by scaling across the variables rather than a change in the overall structure of the spatial precipitation. Furthermore, there is a tendency of increasing extremity with decreasing PC1 and PC2. How able the combined dataset is to distinguish between 1-hour and 24-hour extreme events for PC 1-7 is illustrated in Figure 6. The distinctions between the two event types are clear for all combination of PCs if either PC1 or PC2 5 is included.

The seasonal variation of the sampled extreme events visualised by the two first PCs can be seen in Figure 7. A distinction between summer and non-summer events is clear, reflecting the difference in the seasonal variation between 1-hour and 24hour extreme events.

\section{$10 \quad$ 4.4.2 Cluster analysis}

The K-means clustering algorithm is performed with a predefined number of two and four clusters (Figure 8). The two clusters in Figure 8 left, describe the distinction between 1-hour and 24-hour extreme events with few 1-hour extreme events in the first cluster primarily consisting of 24-hour extreme events and opposite in the second cluster. In Figure 8 right, the two very extreme events on the 06-08-2009 and the 19-06-2013 constitute a separate cluster. These events can be described as severe

15 convective events with very high Maximum 10 minute and Maximum 1 hour intensity and high Ratio between maximum and average 10 minute intensity. The second cluster contains 1-hour extreme events or events sampled as both types of extreme events. The extreme events in the second cluster are clearly convective events, less extreme than in the first cluster but with remarkably high Maximum 1-hour intensity and a large Ratio between maximum and mean depth. The third cluster is dominated by 1-hour extreme events coupled with 24-hour extreme events. Common for all 24-hour extreme events in this cluster is a

20 shorter Duration compared to the rest of the 24-hour extreme events and a relative low Mean depth. The events in cluster three can be characterised as convective events that could be within a front system. The last cluster, cluster four, consists mostly of 24-hour events with characteristics as long Duration, low Ratio between maximum and mean depth and low Maximum 1 hour intensity. These events can be classified as frontal events with little or no convective activity. Two 1-hour extreme events are within this cluster; these differ from the rest of the 1-hour extreme events by long Duration, and large Minimum and Mean depths.

The dendrograms of the two hierarchical clustering methods Ward and Average linkage can be seen in Figure 9. Even though the two dendrograms appear quite different, many similarities can be seen between the two methods when a specific number of clusters is chosen. Figure 10 visualises the first four clusters from the dendrograms. The clusters identified with the Ward 30 method are very similar to the clusters using the K-means clustering method. The clusters identified with the Average linkage method have the same tendency as the other clustering method, though with more focus on the unusual events. If the number of clusters are increased, the Average linkage method will divide the 1-hour and 24-hour extreme events into separate clusters 
Hydrol. Earth Syst. Sci. Discuss., https://doi.org/10.5194/hess-2018-184

Manuscript under review for journal Hydrol. Earth Syst. Sci.

Discussion started: 2 May 2018

(c) Author(s) 2018. CC BY 4.0 License.

just like the other clustering method. For the purpose of modelling spatial rainfall the different types of extreme events described by the K-means clustering method seem more appropriate than the Ward clustering method.

\subsubsection{Stepwise regression}

Linear models for all of the variables are identified by means of stepwise regression. Table 6 specifies the variables in each of

5 the linear models and the goodness of the fit while Table 7 summarises the number of times that each variable is used in the linear models. The linear models in Table 6 consist of between 3 and 10 descriptive variables, with an average of 7.4, which correspond well with the number of independent variables found in the PCA. Six variables are used in more than half of the linear models: Ratio 10 minute, Maximum 24 hour intensity, Mean wet area, Ratio depth, Cell lifetime and Standard deviation of velocity. These variables were also identified as variables that are able to distinguish between 1-hour and 24-hour extreme

10 events. Furthermore, do the six variables correspond well with the variables influencing the first four PCs in the PCA: Ratio 10 min and Ratio depth both largely influence PC1, Maximum 24 hour intensity influence PC2, Standard deviation of velocity influence PC3 and Mean wet area and Cell lifetime influence PC4.

\section{Conclusion}

Spatial rainfall from radar data was analysed using a range of metrics and the findings are in general in accordance with current

15 understanding of spatial rainfall. The seasonal variation and spatial correlation of the analysed extreme events confirm a clear difference between 1-hour and 24-hour extreme events which can be described as a difference between convective and front events. Four sampling strategies for sampling spatial extreme events were analysed and it was found that it is best to sample from only one grid cell to avoid unrealistic long events with sub-events that are meteorologically independent. 1-hour extreme events are very local. It was shown that a least $50 \%$ of sampled extreme events would change if another grid cell within a

20 radius of approximately $5 \mathrm{~km}$ were chosen as sample point, with decreasing similarity in sampled extreme events with increasing distance between the compared grid cells. This study suggests that further development on a sampling strategy for sampling spatial extreme events is needed.

Events were characterised by 16 variables giving a thorough description of the spatio-temporal variability of the events. All

25 variables contribute with information about the analysed extreme events, even though there are correlations suggesting that not all dimensions are necessary. The PCA suggest five to nine dimensions necessary to describe the data, but up to 14 PC's were found significant, implying that more dimensions might be relevant to consider. From the PCA and cluster analysis it was possible to distinguish between 1-hour and 24-hour extreme events and identify four different storm types with varying level of extremity. Variables found important in the PCA and cluster analysis were concluded to be important in the stepwise 30 regression as well. The findings of the three methods supplement each other well and no contradictions between them have been identified. 
Hydrol. Earth Syst. Sci. Discuss., https://doi.org/10.5194/hess-2018-184

Manuscript under review for journal Hydrol. Earth Syst. Sci.

Discussion started: 2 May 2018

(c) Author(s) 2018. CC BY 4.0 License.

(c) (i)

A simple rain cell identification and tracking algorithm was developed for the study to describe the overall tendency in rain cell lifetime, number, direction and velocity of extreme events. For the purpose of this study the relatively simple algorithm proved to be sufficient to give a realistic picture of the related variables.

5

The results of this study conduct the preliminary steps prior to setting up a weather generator with similar properties as highresolution radar rainfall data. The results point out which variables in such a weather generator should be considered independent and which could be co-varied. The study should be considered as a first step into the direction of good practises to find and analyse single storm events in radar rainfall data sets. The tested methods helps to understand the characteristics of

10 the different storm types and the results show which weather regimes should be included to reproduce all relevant situations in which extremes could appear.

\section{Acknowledgement}

The radar data used is a quality-controlled composite product from hydro \& meteo GmbH\&Co.KG based on the polar data product from the Deutscher Wetterdienst (DWD) radar network. Data is owned by the Wupperverband and has been made

15 freely available for this research purpose. Inquiries regarding the data should be addressed to the Wupperverband. 
Hydrol. Earth Syst. Sci. Discuss., https://doi.org/10.5194/hess-2018-184

Manuscript under review for journal Hydrol. Earth Syst. Sci.

Discussion started: 2 May 2018

(c) Author(s) 2018. CC BY 4.0 License.

\section{References}

Akaike, H.: Information theory and an extension of the maximum likelihood principle, 2nd Int. Symp. Inf. Theory. Abstr. Pap., 267-281, 1971.

Anderson, T. W.: An introduction to multivariate statistical analysis, 2nd ed., John Wiley \& Sons., 1984.

5 Arnbjerg-Nielsen, K., Willems, P., Olsson, J., Beecham, S., Pathirana, A., Gregersen, I. . B., Madsen, H. and Nguyen, V.-T.V.: Impacts of climate change on rainfall extremes and urban drainage systems : a review, Water Sci. Technol., 68(1), 16-28, doi:10.2166/wst.2013.251, 2013.

Belachsen, I., Marra, F., Peleg, N. and Morin, E.: Convective rainfall in a dry climate: relations with synoptic systems and flash-flood generation in the Dead Sea region, Hydrol. Earth Syst. Sci., 21(10), 5165-5180, doi:10.5194/hess-21-5165-2017, 102017.

Berndtsson, R. and Niemczynowicz, J.: Spatial and Temporal Scales in Rainfall Some Aspects and Future Perspectives, J. Hydrol., 100, 293-313, doi:10.1016/0022-1694(88)90189-8, 1988.

Bretherton, C. S., Widmann, M., Dymnikov, V. P., Wallace, J. M. and Bladé, I.: The Effective Number of Spatial Degrees of Freedom of a Time-Varying Field, J. Clim., 12(7), 1990-2009, doi:10.1175/1520-0442(1999)012<1990:TENOSD>2.0.CO;2, 151999.

Burton, A., Kilsby, C. G., Fowler, H. J., Cowpertwait, P. S. P. and O’Connell, P. E.: RainSim: A spatial-temporal stochastic rainfall modelling system, Environ. Model. Softw., 23(12), 1356-1369, doi:10.1016/J.ENVSOFT.2008.04.003, 2008.

Butler, D. and Davies, J. W.: Urban drainage, 3rd ed., Spon Press, London, UK., 2011.

Coles, S.: An Introduction to Statistical Modeling of Extreme Values, Springer London, London., 2001.

20 Collier, C. G.: Applications of weather radar systems : a guide to uses of radar data in meteorology and hydrology, Ellis Horwood, Chichester., 1989.

Cormack, R. M.: A Review of Classification, J. R. Stat. Soc. Ser. A, 134(3), 321-367, 1971.

Cowpertwait, P. and O'Connell, P.: A regionalised Neyman-Scott model of rainfall with convective and stratiform cells, Hydrol. Earth Syst. Sci., 1(1), 71-80, 1997.

25 Dixon, M. and Wiener, G.: TITAN: Thunderstorm Identification, Tracking, Analysis, and Nowcasting-A Radar-based Methodology, J. Atmos. Ocean. Technol., 10(6), 785-797, doi:10.1175/1520-0426(1993)010<0785:TTITAA>2.0.CO;2, 1993.

Draper, N. R. and Smith, H.: Applied Regression Analysis, Third., John Wiley \& Sons, Inc., Hoboken, NJ, USA., 1998.

Einfalt, T. and Lobbrecht, A.: Compositing international radar data using a weight-based scheme, in International Symposium 30 on Weather Radar and Hydrology, WRaH, pp. 20-25, IAHS Publ. 351., 2011.

Einfalt, T., Arnbjerg-Nielsen, K., Golz, C., Jensen, N. E., Quirmbach, M., Vaes, G. and Vieux, B.: Towards a roadmap for use of radar rainfall data in urban drainage, J. Hydrol., 299(3-4), 186-202, doi:10.1016/j.jhydrol.2004.08.004, 2004.

ExUS: Extremwertstatistische Untersuchung von Starkniederschlägen in NRW (ExUS) - Veränderung in Dauer, Intensität und 
Hydrol. Earth Syst. Sci. Discuss., https://doi.org/10.5194/hess-2018-184

Manuscript under review for journal Hydrol. Earth Syst. Sci.

Discussion started: 2 May 2018

(c) Author(s) 2018. CC BY 4.0 License.

Raum auf Basis beobachteter Ereignisse und Auswirkungen auf die Eintretenswahrscheinlichkeit, Essen., 2010.

Frerk, I., Treis, A., Einfalt, T. and Jessen, M.: Ten years of quality controlled and adjusted radar precipitation data for North

Rhine Westphalia - methods and objectives, in 9th International Workshop on Precipitation in Urban Areas, St. Moritz, 6-9 December., 2012.

5 Gregersen, I. B., Sørup, H. J. D., Madsen, H., Rosbjerg, D., Mikkelsen, P. S. and Arnbjerg-Nielsen, K.: Assessing future climatic changes of rainfall extremes at small spatio-temporal scales, Clim. Change, 118(3-4), 783-797, doi:10.1007/s10584012-0669-0, 2013.

Handwerker, J.: Cell tracking with TRACE3D - A new algorithm, Atmos. Res., 61(1), 15-34, doi:10.1016/S01698095(01)00100-4, 2002.

10 Hartigan, J. A.: Clustering algorithms, Wiley Publiction in Applied Statistics., 1975.

Hartigan, J. A. and Wong, M. A.: Algorithm AS 136: A K-Means Clustering Algorithm, J. R. Stat. Soc. Ser. C (Applied Stat., 28(1), 100-108, doi:10.2307/2346830, 1979.

Jinno, K., Kawamura, A., Berndtsson, R., Larson, M. and Niemczynowicz, J.: Real-time rainfall prediction at small spacetime scales using a two-dimensional stochastic advection-diffusion model, Water Resour. Res., 29(5), 1489-1504, 15 doi:10.1029/92WR02849, 1993.

Kyznarová, H. and Novák, P.: CELLTRACK - Convective cell tracking algorithm and its use for deriving life cycle characteristics, Atmos. Res., 93(1-3), 317-327, doi:10.1016/j.atmosres.2008.09.019, 2009.

Lance, G. N. and Williams, W. T.: A generalized sorting strategy for computer classifications, Nature, 212, 218, doi:10.1038/212218a0, 1966.

20 Lawley, D. N. and Maxwell, A. E.: Factor analysis as a statistical method, 2nd ed., Butterworth, London, UK., 1963.

Madsen, H., Mikkelsen, P. S., Rosbjerg, D. and Harremoës, P.: Regional estimation of rainfall intensity-duration-frequency curves using generalized least squares regression of partial duration series statistics, Water Resour. Res., 38(11), 21-1-21-11, doi:10.1029/2001WR001125, 2002.

Madsen, H., Arnbjerg-Nielsen, K. and Mikkelsen, P. S.: Update of regional intensity-duration-frequency curves in Denmark:

25 Tendency towards increased storm intensities, Atmos. Res., 92(3), 343-349, doi:10.1016/J.ATMOSRES.2009.01.013, 2009. Mikkelsen, P. S., Harremoës, P. and Rosbjerg, D.: Properties of extreme point rainfall II: Parametric data interpretation and regional uncertainty assessment, Atmos. Res., 37(4), 287-304, doi:10.1016/0169-8095(94)00054-H, 1995.

Mikkelsen, P. S., Madsen, H., Rosbjerg, D. and Harremoës, P.: Properties of extreme point rainfall III: Identification of spatial inter-site correlation structure, Atmos. Res., 40(1), 77-98, doi:10.1016/0169-8095(95)00026-7, 1996.

30 Morrison, D. F.: Multivariate Statistical Methods, McGraw-Hill., 1967.

Murtagh, F.: A Survey of Recent Advances in Hierarchical Clustering Algorithms, Comput. J., 26(4), 354-359, doi:10.1093/comjnl/26.4.354, 1983.

Ochoa-Rodriguez, S., Wang, L. P., Gires, A., Pina, R. D., Reinoso-Rondinel, R., Bruni, G., Ichiba, A., Gaitan, S., Cristiano, E., Van Assel, J., Kroll, S., Murlà-Tuyls, D., Tisserand, B., Schertzer, D., Tchiguirinskaia, I., Onof, C., Willems, P. and Ten 
Hydrol. Earth Syst. Sci. Discuss., https://doi.org/10.5194/hess-2018-184

Manuscript under review for journal Hydrol. Earth Syst. Sci.

Discussion started: 2 May 2018

(c) Author(s) 2018. CC BY 4.0 License.
Hydrology and

Earth System

Sciences

Discussions

(c) (i)

Veldhuis, M. C.: Impact of spatial and temporal resolution of rainfall inputs on urban hydrodynamic modelling outputs: A multi-catchment investigation, J. Hydrol., 531, 389-407, doi:10.1016/j.jhydrol.2015.05.035, 2015.

Onof, C. and Arnbjerg-Nielsen, K.: Quantification of anticipated future changes in high resolution design rainfall for urban areas, Atmos. Res., 92(3), 350-363, doi:10.1016/J.ATMOSRES.2009.01.014, 2009.

5 Peleg, N. and Morin, E.: Convective rain cells: Radar-derived spatiotemporal characteristics and synoptic patterns over the eastern Mediterranean, J. Geophys. Res. Atmos., 117(15), D15116, doi:10.1029/2011JD017353, 2012.

Quirmbach, M., Einfalt, T. and Langstädtler, G.: Climate change analysis of precipitation data for North Rhine-Westphalia, Atmos. Res., 109-110, 1-13, doi:10.1016/j.atmosres.2011.10.014, 2012.

Rawlings, J. O., Pantula, S. G. and Springer, D. A. D.: Applied Regression Analysis: A Research Tool, Second Edition, 2nd

10 ed., Springer, New York., 1998.

Schilling, W.: Rainfall data for urban hydrology: what do we need?, Atmos. Res., 27(1-3), 5-21, doi:10.1016/01698095(91)90003-F, 1991.

Sørup, H. J. D., Christensen, O. B., Arnbjerg-Nielsen, K. and Mikkelsen, P. S.: Downscaling future precipitation extremes to urban hydrology scales using a spatio-temporal Neyman-Scott weather generator, Hydrol. Earth Syst. Sci., 20(4), 1387-1403,

15 doi:10.5194/hess-20-1387-2016, 2016.

Thorndahl, S., Beven, K. J., Jensen, J. B. and Schaarup-Jensen, K.: Event based uncertainty assessment in urban drainage modelling, applying the GLUE methodology, J. Hydrol., 357(3-4), 421-437, doi:10.1016/j.jhydrol.2008.05.027, 2008.

Thorndahl, S., Einfalt, T., Willems, P., Nielsen, J. E., ten Veldhuis, M.-C., Arnbjerg-Nielsen, K., Rasmussen, M. R. and Molnar, P.: Weather radar rainfall data in urban hydrology, Hydrol. Earth Syst. Sci. Discuss., 1(October), 1-37, 20 doi:10.5194/hess-2016-517, 2016.

Vaes, G., Willems, P. and Berlamont, J.: Rainfall input requirements for hydrological calculations, Urban Water, 3(1-2), 107112, doi:10.1016/S1462-0758(01)00020-6, 2001.

Wilks, D. S. and Wilby, R. L.: The weather generation game: a review of stochastic weather models, Prog. Phys. Geogr., 23(3), 329-357, doi:10.1191/030913399666525256, 1999.

25 Willems, P., Olsson, J., Arnbjerg-Nielsen, K., Beecham, S., Pathirana, A., Gregersen, I. B., Madsen, H. and Nguyen, V.-T.V.: Impacts of Climate Change on Rainfall Extremes and Urban Drainage, IWA publishing, London, UK., 2012. 
Hydrol. Earth Syst. Sci. Discuss., https://doi.org/10.5194/hess-2018-184

Manuscript under review for journal Hydrol. Earth Syst. Sci.

Discussion started: 2 May 2018

(c) Author(s) 2018. CC BY 4.0 License.

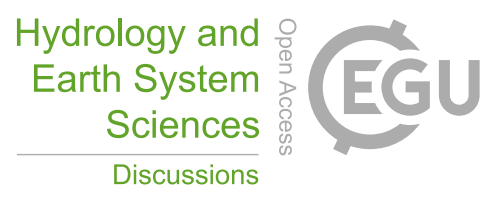

(c) $\underset{\mathrm{BY}}{(i)}$
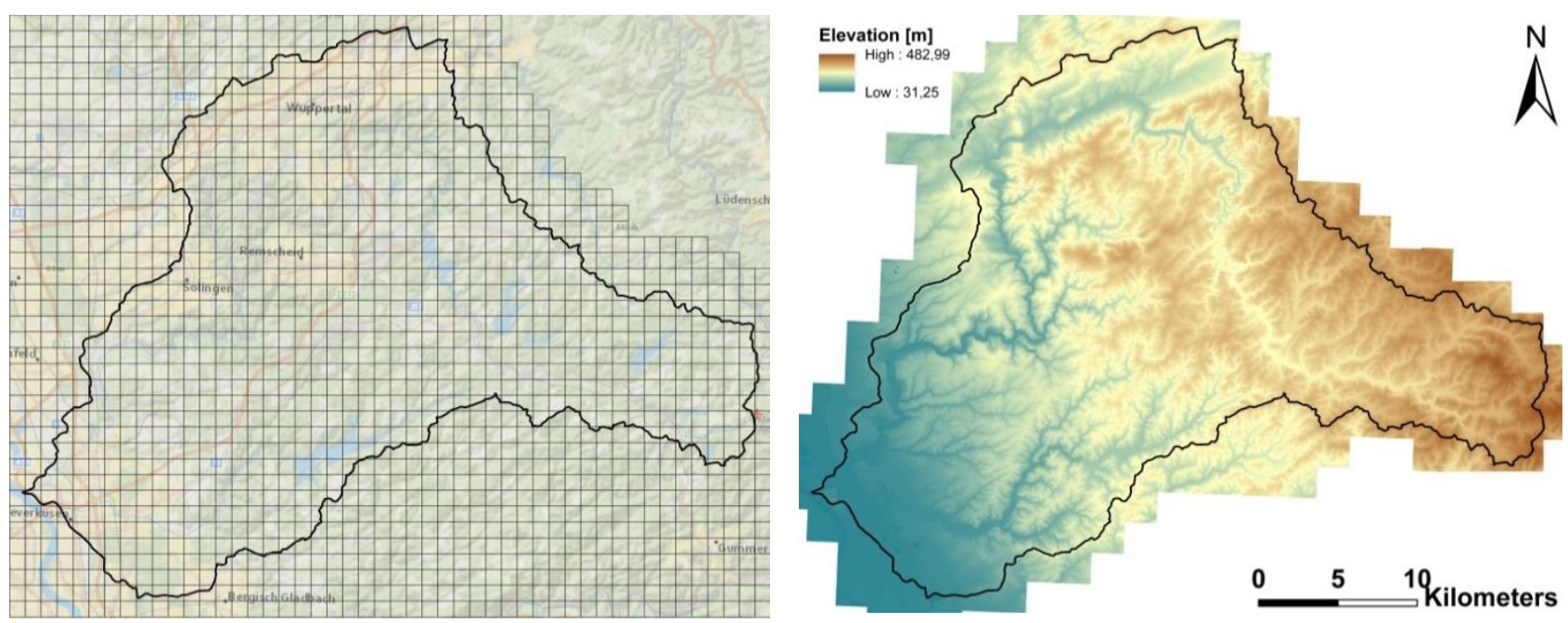

Figure 1: Overview of the case area. Left: Gridded area represents the part of the catchment where time series data is produced. Right: Elevation in the Wupper catchment.

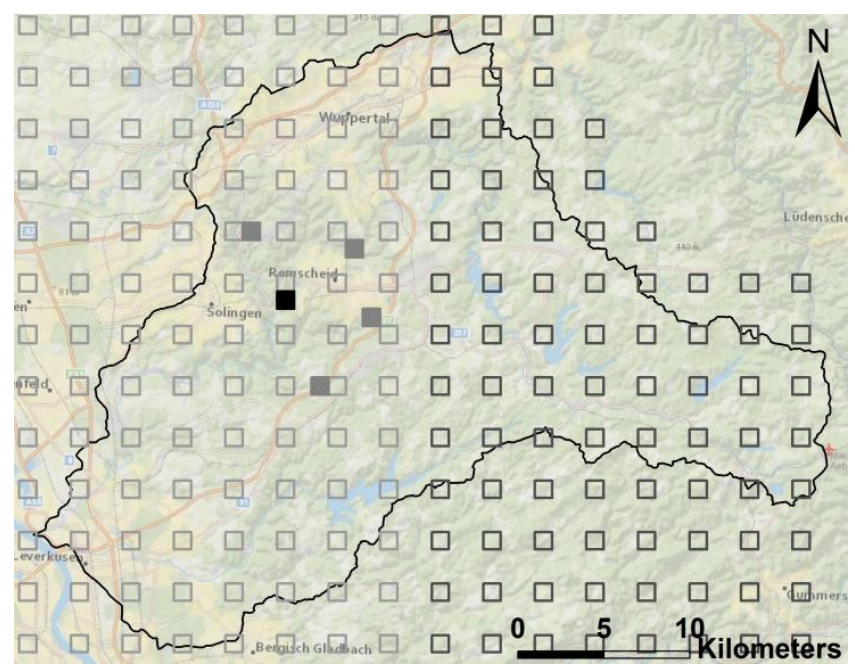

Figure 2: Overview of the four sampling strategies: - SS1: Filled black cell, SS2: Black and grey filled cells, SS3: cells outlined in light grey and SS4: cells outlined in light and dark grey. 
Hydrol. Earth Syst. Sci. Discuss., https://doi.org/10.5194/hess-2018-184

Table 1: Description of variables

\begin{tabular}{|c|c|c|c|}
\hline Variable & Short name & Unit & Description \\
\hline Duration & Duration & Hours & $\begin{array}{l}\text { From start to end with an extension of } 2 \text { hours in each end to consider the event } \\
\text { in the entire case area. }\end{array}$ \\
\hline Intensity & $\begin{array}{l}\text { Max } 10 \mathrm{~min} \\
\text { Ratio } 10 \mathrm{~min} \\
\text { Max } 1 \mathrm{~h} \\
\text { Max } 24 \mathrm{~h}\end{array}$ & $\begin{array}{l}\mathrm{mm} \min ^{-1} \\
- \\
\mathrm{mm} \min ^{-1} \\
\mathrm{~mm} \min ^{-1}\end{array}$ & $\begin{array}{l}\text { Maximum average intensity for } 10 \text { minutes. } \\
\text { Ratio between max } 10 \text { minute and mean } 10 \text { minute intensity. } \\
\text { Maximum average intensity for } 1 \text { hour. } \\
\text { Maximum average intensity for } 24 \text { hours. }\end{array}$ \\
\hline Wet Area & Mean wet A & - & $\begin{array}{l}\text { Average ratio of cells with precipitation (wet cells) from each time step of the } \\
\text { event. }\end{array}$ \\
\hline Depth & $\begin{array}{l}\text { Min depth } \\
\text { Max depth } \\
\text { Mean depth } \\
\text { Ratio depth }\end{array}$ & $\begin{array}{l}\mathrm{mm} \\
\mathrm{mm} \\
\mathrm{mm} \\
-\end{array}$ & $\begin{array}{l}\text { Value of the grid cell with the lowest depth in the case area. } \\
\text { Value of the grid cell with the highest depth in the case area. } \\
\text { Average depth considering all cells in the case area. } \\
\text { Ratio between max depth and mean depth. }\end{array}$ \\
\hline $\begin{array}{l}\text { Rain cell } \\
\text { properties }\end{array}$ & $\begin{array}{l}\text { Cell num } \\
\text { Cell life }\end{array}$ & min & $\begin{array}{l}\text { Number of tracked rain cell in the rain event. } \\
\text { Average lifetime of the rain cells in the event. }\end{array}$ \\
\hline Movement & $\begin{array}{l}\text { Mean vel } \\
\text { Sd vel } \\
\text { Mean dir } \\
\text { Sd dir }\end{array}$ & $\begin{array}{l}\mathrm{m} \mathrm{s}^{-1} \\
\mathrm{~m} \mathrm{~s}^{-1} \\
\text { Degrees } \\
\text { Degrees }\end{array}$ & $\begin{array}{l}\text { Mean rain cell velocity } \\
\text { Standard deviation of velocity. } \\
\text { Mean moving direction of rain cells, compass degrees. } \\
\text { Standard deviation of direction. }\end{array}$ \\
\hline
\end{tabular}

Table 2: Results from the four sampling strategies described in Sect. 3.2

\begin{tabular}{|c|c|c|c|c|c|c|c|}
\hline $\begin{array}{l}\text { Sampling } \\
\text { strategy }\end{array}$ & $\begin{array}{l}\text { Number of } \\
\text { events total }\end{array}$ & $\begin{array}{l}\text { Average } \\
\text { event length } \\
\text { [h] }\end{array}$ & $\begin{array}{l}\text { Average } \\
\text { number of grid } \\
\text { cells }\end{array}$ & $\begin{array}{l}\text { Proportion of } \\
\text { events in } \\
\text { winter }\end{array}$ & $\begin{array}{l}\text { Proportion of } \\
\text { events in } \\
\text { spring }\end{array}$ & $\begin{array}{l}\text { Proportion of } \\
\text { events in } \\
\text { summer }\end{array}$ & $\begin{array}{l}\text { Proportion of } \\
\text { events in fall }\end{array}$ \\
\hline SS1 (1 grid cell) & 879 & 65.29 & 1.00 & 0.21 & 0.27 & 0.28 & 0.24 \\
\hline $\begin{array}{l}\mathrm{SS} 2(5 \text { grid } \\
\text { cells) }\end{array}$ & 843 & 80.61 & 4.38 & 0.22 & 0.27 & 0.27 & 0.25 \\
\hline $\begin{array}{l}\text { SS3 (west side } \\
\text { of the } \\
\text { mountain) }\end{array}$ & 439 & 219.88 & 67.74 & 0.28 & 0.27 & 0.18 & 0.27 \\
\hline $\begin{array}{l}\text { SS4 (total } \\
\text { catchment) }\end{array}$ & 297 & 347.48 & 122.61 & 0.31 & 0.27 & 0.16 & 0.26 \\
\hline
\end{tabular}


Hydrol. Earth Syst. Sci. Discuss., https://doi.org/10.5194/hess-2018-184
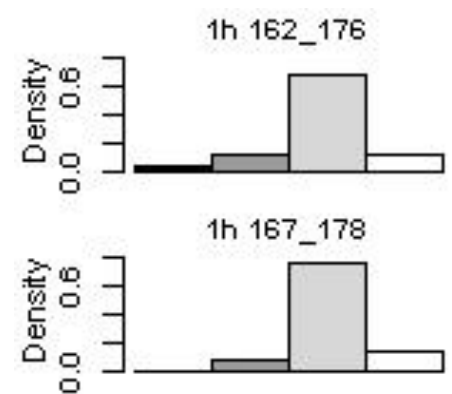

1h 163_181

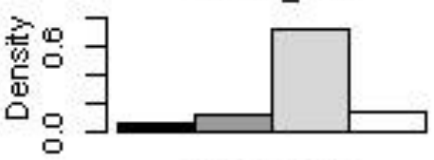

1h 159_180

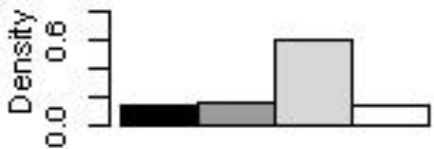

1h 158_174

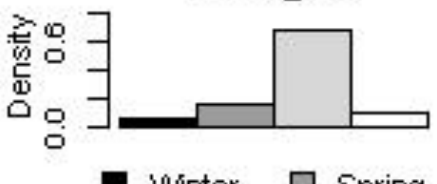

Winter

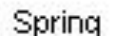

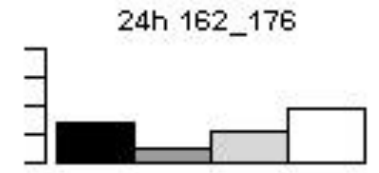

24h 167_178

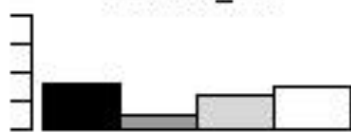

24h 163_181

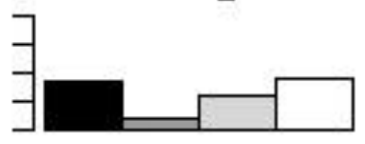

24h 159_180

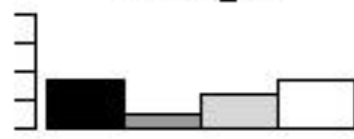

24h 158_174

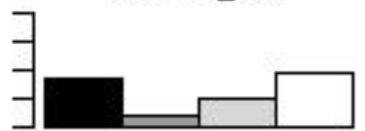

$\square$ Summer $\square$ Fall

Figure 3: Seasonal variation in occurrence of extreme events for each of the five grid cells filled in Figure 2. 
Hydrol. Earth Syst. Sci. Discuss., https://doi.org/10.5194/hess-2018-184

Manuscript under review for journal Hydrol. Earth Syst. Sci.

Discussion started: 2 May 2018

(c) Author(s) 2018. CC BY 4.0 License.
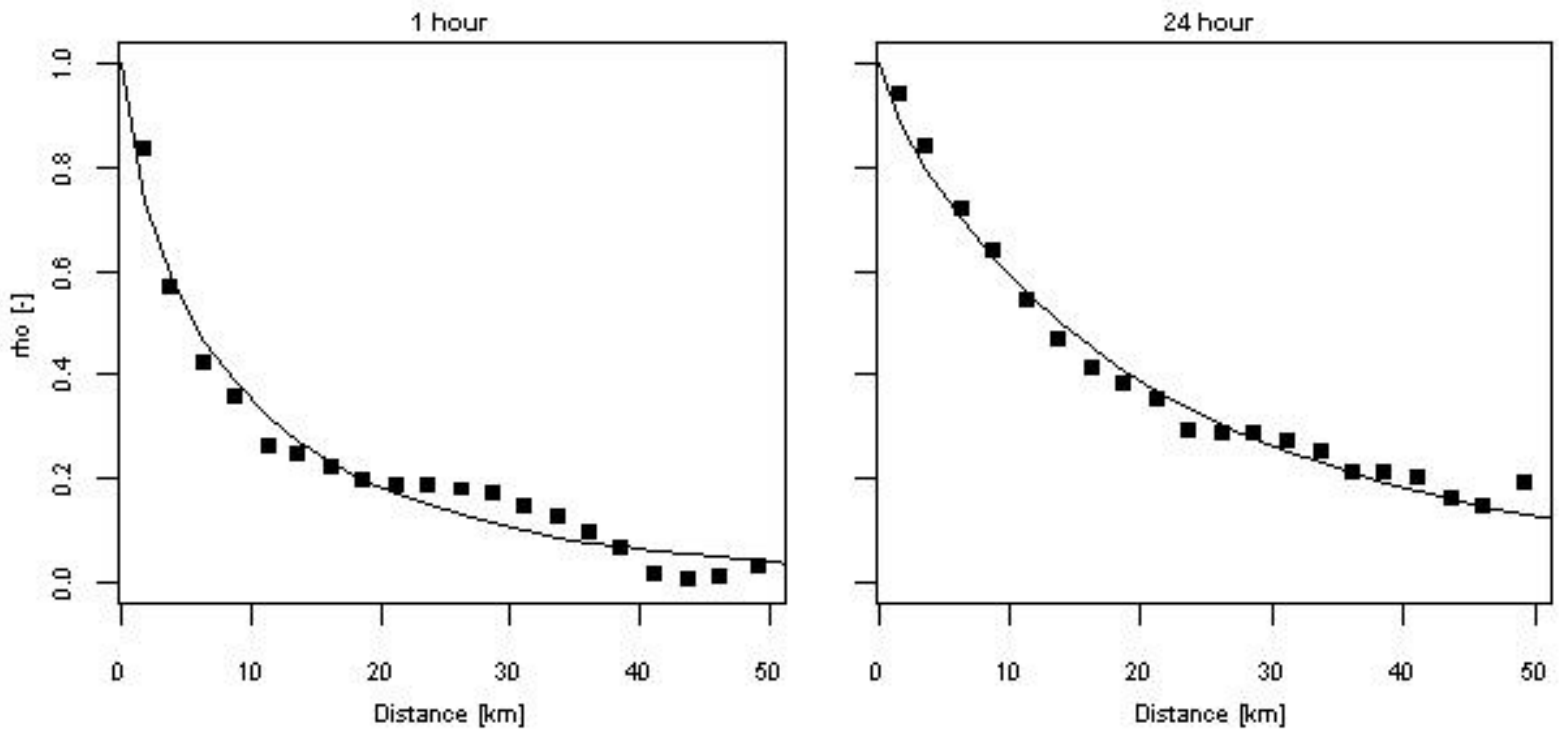

- Radar data - Exp model

Figure 4: Spatial correlation calculated for binned data of 100 grid cells, 4950 pairs.

Table 3: Comparison of the five grid cells filled in Figure 2, the black filled grid cell is used as reference.

\begin{tabular}{lr|rrrr}
\hline Name & 162_176 & 167_178 & 163_181 & 159_180 & 158_175 \\
\hline distance (S,E) [km] & $(0,0)$ & $(-4,-1)$ & $(-3,7)$ & $(3,5)$ & $(4,-3)$ \\
distance [km] & 0.00 & 5.39 & 5.10 & 5.00 & 4.47 \\
Similar 1-hour & 39 & 19 & 21 & 23 & 22 \\
Similar 24-hour & 39 & 31 & 32 & 30 & 32 \\
Similar 1-hour [\%] & 100 & 49 & 54 & 59 & 56 \\
Similar 24-hour [\%] & 100 & 79 & 82 & 77 & $82)$ \\
\hline
\end{tabular}


Hydrol. Earth Syst. Sci. Discuss., https://doi.org/10.5194/hess-2018-184

Manuscript under review for journal Hydrol. Earth Syst. Sci.

Discussion started: 2 May 2018

(C) Author(s) 2018. CC BY 4.0 License.
Hydrology and

Earth System

Sciences

Discussions

(c) (1)

Table 4: Overview of the 12 events sampled as both 1-hour and 24-hour extreme event. The numbers refer to the tables in the supplementary material.

\begin{tabular}{lrr}
\hline Date (LT) & 1-hour & 24-hour \\
\hline $17-07-2001$ & 3 & 2 \\
$19-08-2002$ & 6 & 6 \\
$05-10-2002$ & 7 & 7 \\
$10-09-2004$ & 12 & 14 \\
$29-06-2005$ & 16 & 19 \\
$29-09-2005$ & 19 & 22 \\
$06-08-2007$ & 22 & 25 \\
$18-08-2007$ & 23 & 26 \\
$10-08-2010$ & 29 & 30 \\
$19-06-2013$ & 36 & 37 \\
$22-07-2013$ & 37 & 38 \\
$06-09-2013$ & 39 & 39 \\
\hline
\end{tabular}

5 Table 5: Composition of variables for the first nine PC's in a combined PCA including both 1-hour and 24-hour extreme events.

\begin{tabular}{|c|c|c|c|c|c|c|c|c|c|}
\hline & PC1 & PC2 & PC3 & PC4 & PC5 & PC6 & PC7 & PC8 & PC9 \\
\hline Duration & 0.25 & -0.27 & 0.10 & -0.40 & 0.21 & -0.11 & 0.09 & -0.30 & 0.06 \\
\hline Max 10 min intensity & -0.29 & -0.31 & 0.02 & -0.17 & -0.23 & 0.01 & -0.18 & 0.16 & 0.16 \\
\hline Ratio $10 \mathrm{~min}$ & -0.28 & -0.27 & 0.05 & -0.33 & -0.23 & -0.06 & -0.10 & -0.10 & 0.10 \\
\hline Max $1 \mathrm{~h}$ intensity & -0.32 & -0.31 & -0.10 & -0.02 & -0.10 & 0.17 & -0.07 & -0.06 & 0.17 \\
\hline Max 24h intensity & -0.10 & -0.40 & -0.16 & 0.27 & -0.08 & 0.15 & -0.31 & 0.32 & -0.27 \\
\hline Mean wet area & 0.20 & -0.04 & 0.11 & 0.62 & -0.27 & -0.04 & -0.17 & -0.19 & -0.15 \\
\hline Min depth & 0.32 & -0.30 & 0.10 & 0.01 & 0.15 & -0.13 & 0.03 & -0.08 & 0.01 \\
\hline Max depth & 0.16 & -0.46 & 0.05 & 0.04 & 0.11 & 0.02 & 0.01 & -0.07 & -0.18 \\
\hline Mean depth & 0.30 & -0.35 & 0.08 & 0.00 & 0.11 & -0.09 & 0.01 & -0.03 & -0.12 \\
\hline Ratio depth & -0.33 & 0.01 & -0.20 & -0.05 & 0.07 & 0.25 & 0.23 & -0.46 & -0.57 \\
\hline Number of rain cells & 0.26 & -0.03 & -0.22 & -0.12 & 0.25 & 0.63 & 0.14 & 0.46 & 0.02 \\
\hline Rain cell life time & -0.19 & -0.21 & 0.23 & 0.41 & 0.06 & 0.25 & 0.54 & -0.14 & 0.50 \\
\hline Mean velocity & 0.30 & 0.08 & 0.20 & -0.16 & -0.46 & 0.19 & -0.17 & -0.03 & 0.18 \\
\hline Sd velocity & 0.28 & 0.03 & -0.33 & -0.06 & -0.30 & 0.43 & -0.12 & -0.46 & 0.13 \\
\hline Mean direction & 0.15 & -0.11 & -0.37 & -0.06 & -0.53 & -0.29 & 0.61 & 0.23 & -0.14 \\
\hline Sd direction & 0.02 & -0.05 & -0.71 & 0.16 & 0.25 & -0.29 & -0.18 & -0.13 & 0.38 \\
\hline Proportion of variance & 33.94 & 23.57 & 8.81 & 8.64 & 7.14 & 5.24 & 3.50 & 2.93 & 2.55 \\
\hline Prop. of variance cumulative & 33.94 & 57.51 & 66.32 & 74.97 & 82.11 & 87.35 & 90.85 & 93.78 & 96.32 \\
\hline
\end{tabular}


Hydrol. Earth Syst. Sci. Discuss., https://doi.org/10.5194/hess-2018-184

Manuscript under review for journal Hydrol. Earth Syst. Sci.

Discussion started: 2 May 2018

(c) Author(s) 2018. CC BY 4.0 License.
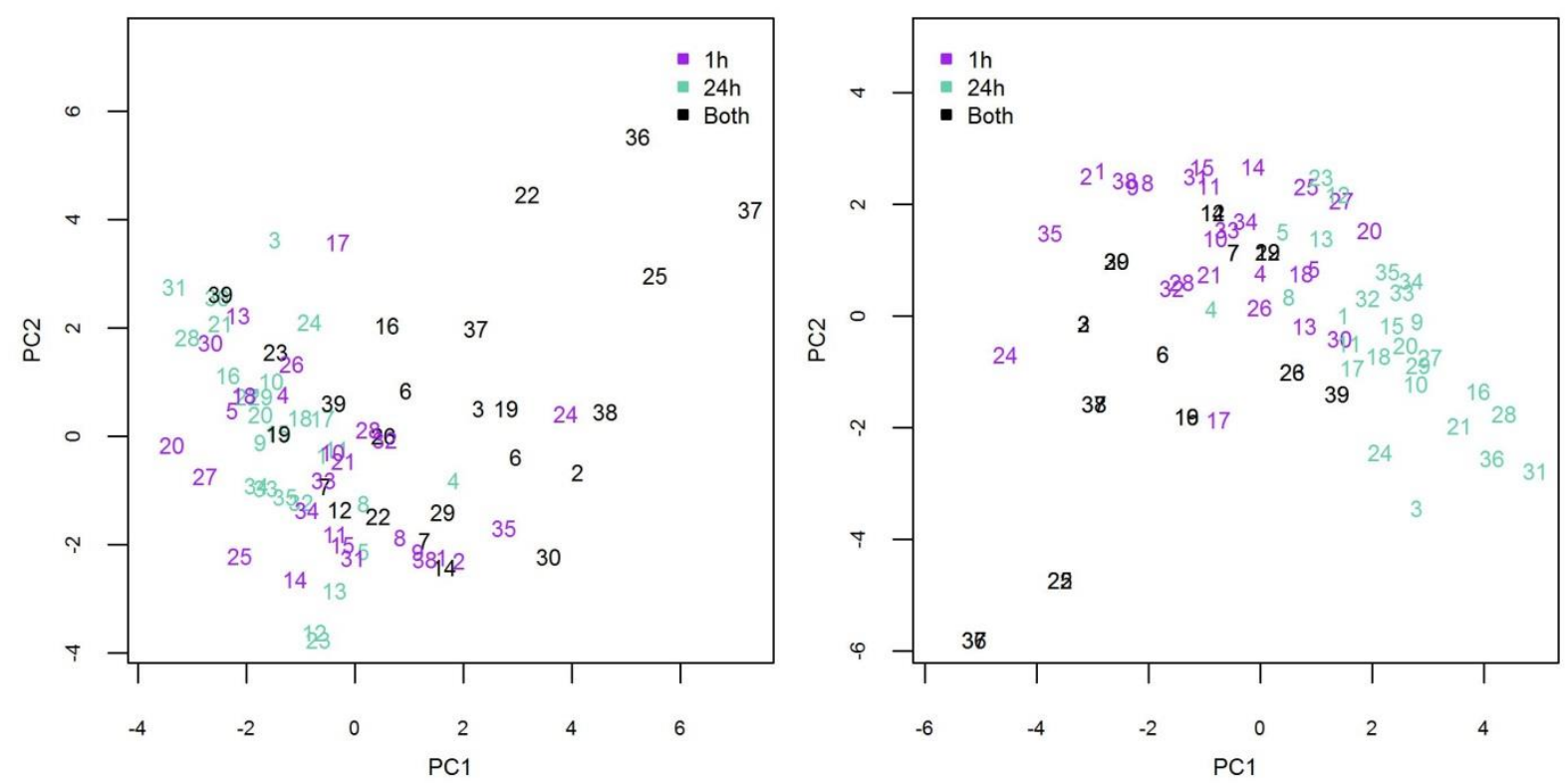

Figure 5: Projection of the extreme events into the two first PC's. Numbers refer to the tables in the supplementary material. Events sampled both as 1-hour and 24-hour extreme events are marked in black, 1-hour extreme events are marked in purple and 24-hour extreme events are marked in blue. Left: Principal component analysis performed on 24-hour dataset and 1-hour extreme events are projected into the same coordinate system. Right: 1-hour and 24-hour extreme events are treated as one dataset, with a combined PCA. 
Hydrol. Earth Syst. Sci. Discuss., https://doi.org/10.5194/hess-2018-184 Manuscript under review for journal Hydrol. Earth Syst. Sci.

Discussion started: 2 May 2018

(c) Author(s) 2018. CC BY 4.0 License.
Hydrology and

Earth System

Sciences

Discussions

(c) (i)

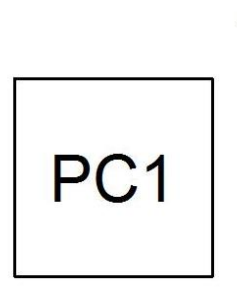

$\begin{array}{lll}-6 & -2 & 2\end{array}$
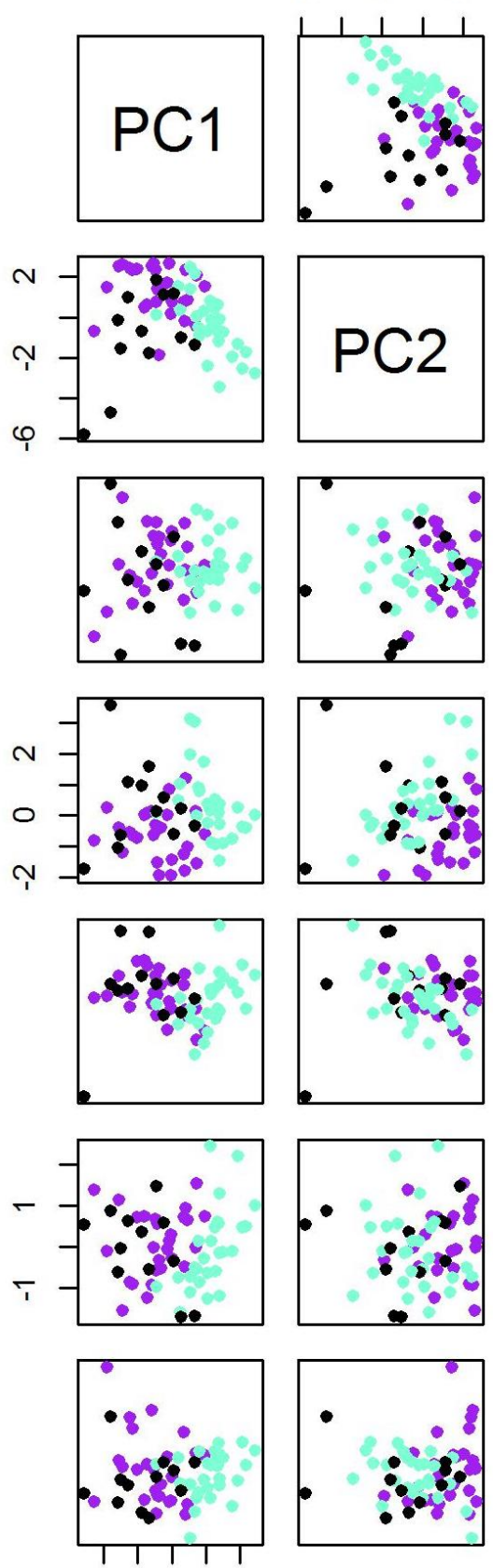

$\begin{array}{lll}-4 & 0 & 4\end{array}$
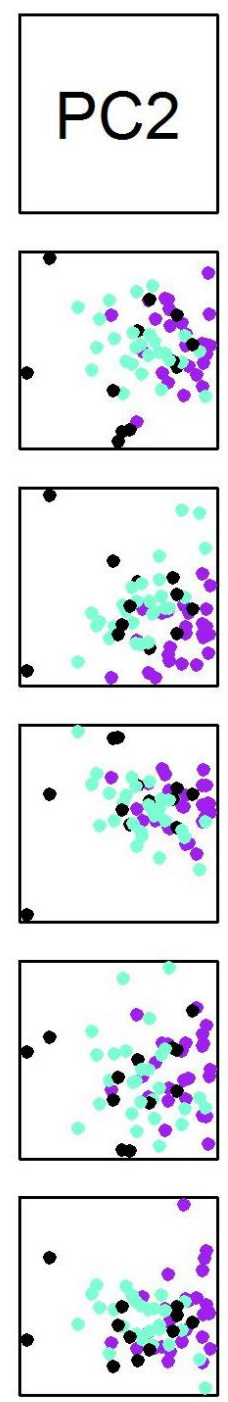
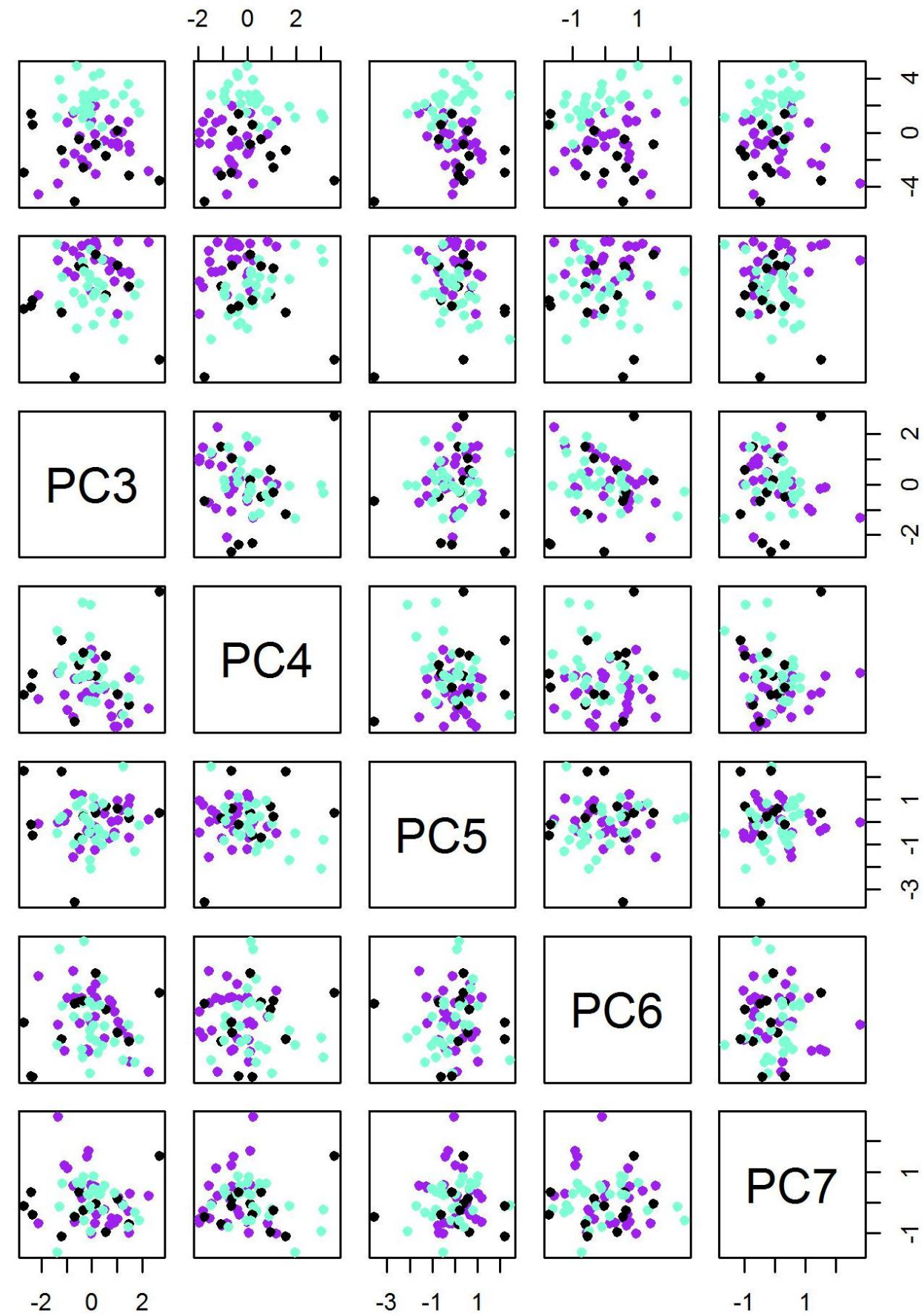

$\begin{array}{lll}-3 & -1 & 1\end{array}$

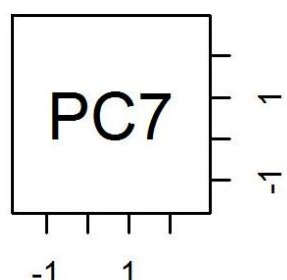

Figure 6: Extreme events projected into PC1 to PC7. 1-hour extreme events are shown in purple, 24-hour extreme events in blue and event sampled with both sampling methods in black. 
Hydrol. Earth Syst. Sci. Discuss., https://doi.org/10.5194/hess-2018-184

Manuscript under review for journal Hydrol. Earth Syst. Sci.

Discussion started: 2 May 2018

(c) Author(s) 2018. CC BY 4.0 License.

(c) (i)
Hydrology and

Earth System

Sciences

Discussions

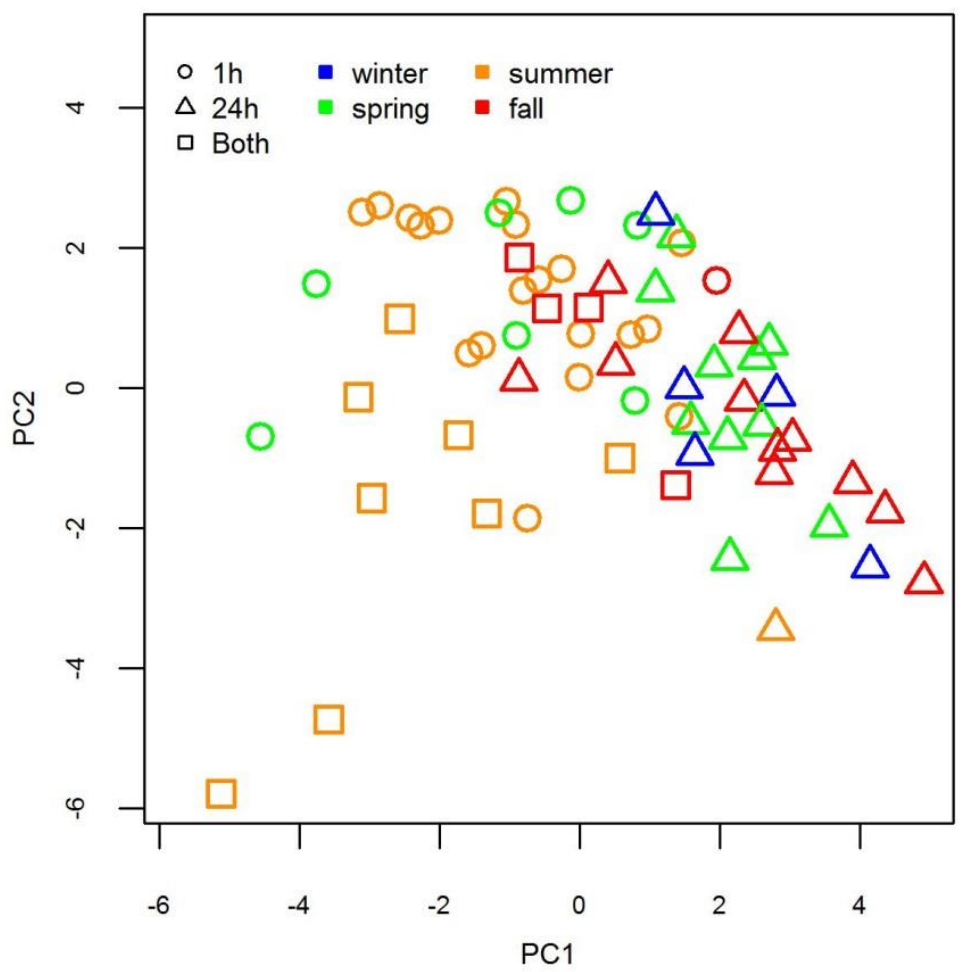

Figure 7: Projection of extreme events into the two first PC's for the combined dataset. Colours indicate season (winter, spring, summer and fall) and shape indicate extreme event type.
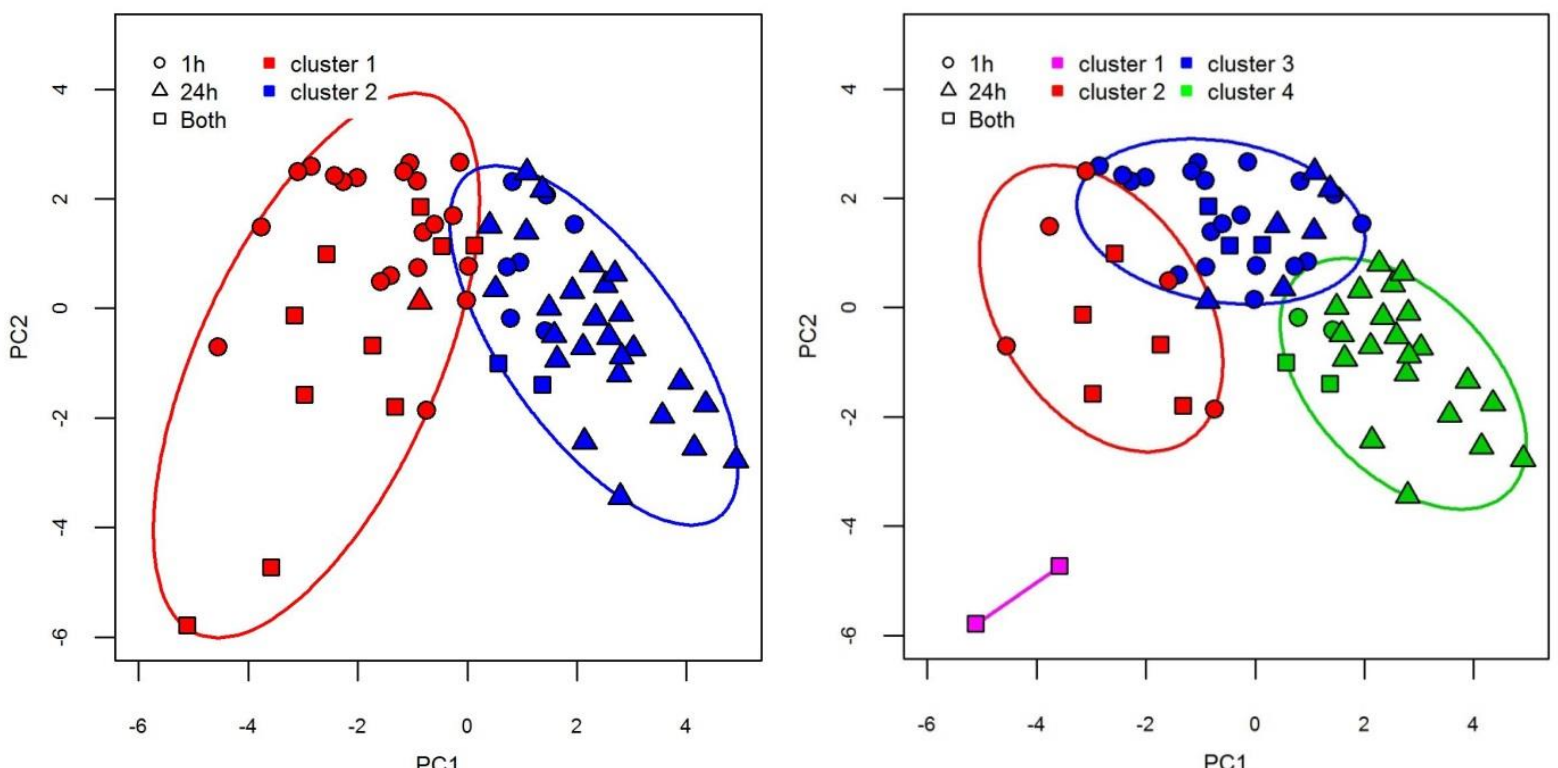

Figure 8: K-means cluster analysis performed on 1-hour and 24-hour data. Left: Pre-defined number of two clusters. Right: Pre-defined number of four clusters. 
Hydrol. Earth Syst. Sci. Discuss., https://doi.org/10.5194/hess-2018-184

Manuscript under review for journal Hydrol. Earth Syst. Sci.

Discussion started: 2 May 2018

(c) Author(s) 2018. CC BY 4.0 License.

(c) (1)
Hydrology and

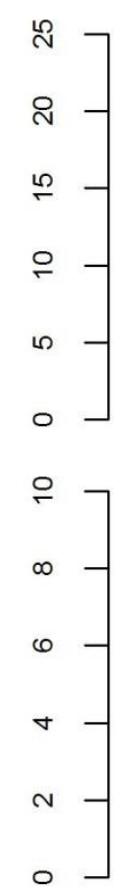

Figure 9: Dendrogram performed on 1-hour and 24-hour extreme events with Ward (top) and Average linkage (bottom) method. 
Hydrol. Earth Syst. Sci. Discuss., https://doi.org/10.5194/hess-2018-184

Manuscript under review for journal Hydrol. Earth Syst. Sci.

Discussion started: 2 May 2018

(c) Author(s) 2018. CC BY 4.0 License.

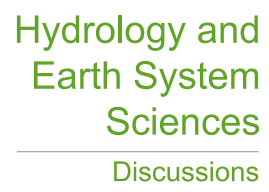

(c) (1)
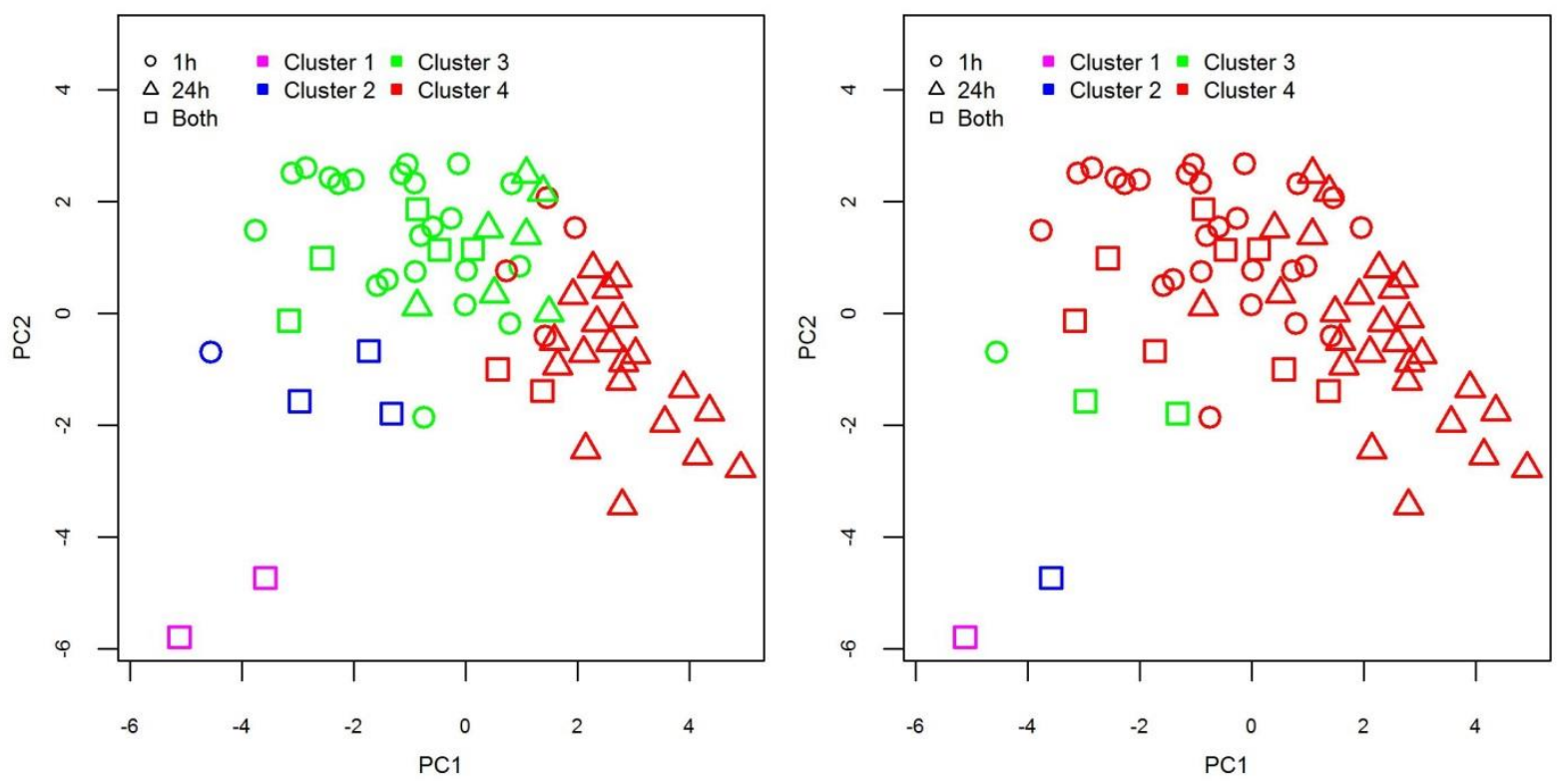

Figure 10: Graphical representation of the first four clusters from the hierarchical clustering methods. Left: Ward. Right: Average linkage. 
Hydrol. Earth Syst. Sci. Discuss., https://doi.org/10.5194/hess-2018-184

Manuscript under review for journal Hydrol. Earth Syst. Sci.

Discussion started: 2 May 2018

(c) Author(s) 2018. CC BY 4.0 License.
Hydrology and

Earth System

Sciences

Discussions

(c) (i)

Table 6: Linear models for each of the variables, using stepwise regression to simplify the models.

\begin{tabular}{|c|c|c|c|}
\hline & Variables, (number of variables) & AIC & $\mathrm{r}^{2}$ \\
\hline Duration & $\begin{array}{l}\text { (8) min depth, mean wet a, mean vel, ratio } 10 \min , \max 10 \mathrm{~min}, \max \text { depth, } \max 24 \mathrm{~h} \text {, cell } \\
\text { life }\end{array}$ & -157.46 & 0.88 \\
\hline Max 10min & $\begin{array}{l}\text { (10) max } 1 \mathrm{~h} \text {, ratio } 10 \mathrm{~min} \text {, ratio depth, duration, mean wet a, max } 24 \mathrm{~h} \text {, sd dir, cell life, mean } \\
\text { depth, cell num }\end{array}$ & -250.12 & 0.96 \\
\hline Ratio $10 \mathrm{~min}$ & $\begin{array}{l}\text { (9) } \max 10 \mathrm{~min}, \max 24 \mathrm{~h} \text {, duration, ratio depth, mean wet a, mean depth, cell life, sd vel, } \\
\text { mean dir }\end{array}$ & -194.83 & 0.93 \\
\hline Max $1 \mathrm{~h}$ & $\begin{array}{l}\text { (9) max } 10 \mathrm{~min} \text {, ratio depth, cell life, sd dir, sd vel, mean dir, max 24h, ratio } 10 \mathrm{~min} \text {, mean } \\
\text { vel }\end{array}$ & -273.07 & 0.97 \\
\hline Max 24h & (6) $\max 1 \mathrm{~h}$, max depth, duration, cell life, ratio $10 \mathrm{~min}$, max $10 \mathrm{~min}$ & -133 & 0.83 \\
\hline Mean wet A & $\begin{array}{l}\text { (10) ratio depth, ratio } 10 \min , \max 24 \mathrm{~h}, \max 10 \mathrm{~min} \text {, duration, max depth, min depth, mean } \\
\text { vel, cell num, max } 1 \mathrm{~h}\end{array}$ & -69.44 & 0.64 \\
\hline Min depth & (6) mean depth, max depth, cell life, duration, mean vel, mean wet A & -229.14 & 0.95 \\
\hline Max depth & $\begin{array}{l}\text { (10) mean depth, max } 1 \mathrm{~h} \text {, ratio depth, max } 24 \mathrm{~h} \text {, cell life, duration, min depth, mean dir, } \\
\text { mean wet } A \text {, sd vel }\end{array}$ & -284.67 & 0.98 \\
\hline Mean depth & $\begin{array}{l}\text { (9) min depth, max depth, } \max 1 \mathrm{~h} \text {, cell life, ratio depth, mean dir, max } 24 \mathrm{~h} \text {, ratio } 10 \mathrm{~min} \text {, } \\
\max 10 \mathrm{~min}\end{array}$ & -323.57 & 0.99 \\
\hline Ratio depth & (7) mean vel, max depth, mean depth, sd vel, max $24 \mathrm{~h}$, cell life, sd dir & 83.48 & 0.69 \\
\hline Cell num & (4) sd vel, ratio $10 \mathrm{~min}$, mean wet $\mathrm{A}$, max depth & -36.61 & 0.41 \\
\hline Cell life & $\begin{array}{l}\text { (10) } \max 1 \mathrm{~h} \text {,ratio } 10 \mathrm{~min} \text {, sd dir, } \max 10 \mathrm{~min} \text {, ratio depth, sd vel, mean dir, max } 24 \mathrm{~h} \text {, mean } \\
\text { wet } \mathrm{A} \text {, min depth }\end{array}$ & -86.49 & 0.71 \\
\hline Mean vel & (4) ratio depth, sd vel, sd dir, cell life & -84.71 & 0.68 \\
\hline Sd vel & (5) mean vel, sd dir, cell num, ratio depth, mean wet A & -56.58 & 0.55 \\
\hline Mean dir & (6) sd vel, mean depth, sd dir, ratio $10 \mathrm{~min}$, max $1 \mathrm{~h}$, duration & -19.33 & 0.28 \\
\hline Sd dir & (5) mean vel, sd vel, ratio depth, mean dir, cell life & -28.15 & 0.35 \\
\hline Average & & -133.98 & 0.74 \\
\hline
\end{tabular}


Hydrol. Earth Syst. Sci. Discuss., https://doi.org/10.5194/hess-2018-184

Manuscript under review for journal Hydrol. Earth Syst. Sci.

Discussion started: 2 May 2018

(c) Author(s) 2018. CC BY 4.0 License.

(c) (1)

Table 7: Number of times each of the variables is used, when setting up linear models for all variables.

\begin{tabular}{lr}
\hline & Times used \\
\hline Duration & 7 \\
Max 10min intensity & 7 \\
Ratio 10min & 9 \\
Max 1h intensity & 7 \\
Max 24h intensity & 9 \\
Mean wet area & 8 \\
Min depth & 5 \\
Max depth & 7 \\
Mean depth & 6 \\
Ratio depth & 10 \\
Number of rain cells & 3 \\
Rain cell life time & 11 \\
Mean velocity & 7 \\
Sd velocity & 9 \\
Mean direction & 6 \\
Sd direction & 7 \\
\hline
\end{tabular}

